\title{
The Determination of Safe Concentration of Non-Carcinogenic Toluene in Surabaya Printing
}

\section{Penentuan Konsentrasi Aman Toluena Non Karsinogenik di Percetakan Surabaya}

\author{
Ahmad Rido'i Yuda Prayogi ${ }^{1}$, Abdul Rohim Tualeka ${ }^{2}$, Ahsan ${ }^{3}$, Pudji Rahmawati ${ }^{4}$, Syamsiar S \\ Russeng $^{5}$, Indri H Susilowati ${ }^{6}$ \\ 1,2Department of Occupational Safety and Health, Faculty of Public Health, Universitas Airlangga \\ Campus C Mulyorejo, Surabaya, East Java, 60115 Indonesia \\ ${ }^{3}$ Faculty of Medical, Universitas Brawijaya \\ Jalan Veteran Malang, East Java 65145, Indonesia \\ ${ }^{4}$ Department of Development of Islamic Society, Universitas Islam Negeri Sunan Ampel Surabaya \\ Jalan Ahmad Yani No. 117 Surabaya, East Java 60211 Indonesia \\ ${ }^{5}$ Department of Occupational Health and Safety, Faculty of Public Health, Universitas Hassanudin \\ Jalan Perintis Kemerdekaan KM. 10, Tamalanrea, Makassar, South Sulawesi 90245 Indonesia \\ ${ }^{6}$ Department of Occupational Health and Safety, Faculty Public Health Faculty, Universitas Indonesia, \\ Building C, 1st Floor Faculty of Public Health Universitas Indonesia, Depok, West Java 16424 Indonesia
}

\begin{abstract}
Introduction: Safe concentrations of non-carcinogenic toluene can cause adverse effects on health. Based on the results of a research, toxic effects on toluene exposure can cause cancerous (leuikimia) and non-cancerous (aplastic anemia). The Research objective to determine the safe concentration of non-carcinogenic toluene in Surabaya printing. Methods: The research design used was observational analytic, cross sectional research design with a quantitative approach. The research location was a printing press in Surabaya. The variables in this study were the concentration of toluene levels (ppm) and RQ in workers. Total population was 37 workers, while the study sample was taken using accidental sampling method with a total sample of 30 respondents. The formula for determining the concentration of toluene non carcinogen intake is (CxRxtExfExDt): (Wbx30x365). Results: The concentration value of toluene exposure was greater than the standard set by labor regulations No. 5 of 2018 about occupational health and safety of the work environment by $0.2 \mathrm{ppm}$. A total of $10 \%$ of workers falls under normal category, $73 \%$ above normal category and $27 \%$ below normal category. Conclusion: In this study, we found new findings, viz the concentration of toluene exposure in Surabaya printing area was above normal with a concentration of $0.2 \mathrm{ppm}$ and this is considered not normal.
\end{abstract}

Keywords: non carcinogenic toluene, safe concentration, surabaya printing, toluene

\section{ABSTRAK}

Pendahuluan: Konsentrasi aman toluene non-karsinogenik dapat menyebabkan efek buruk pada kesehatan. Berdasarkan hasil penelitian, efek toksik terhadap paparan toluen dapat menyebabkan penyakit kanker (leuikimia) dan non-kanker (anemia aplastik). Tujuan penelitain untuk mengetahui konsentrasi aman toluena non karsinogenik di percetakan Surabaya. Metode: Desain penelitian yang digunakan adalah analitik observasional, desain penelitian cross sectional dengan pendekatan kuantitatif. Lokasi penelitian adalah percetakan di daerah Surabaya. Variabel dalam penelitian ini adalah konsentrasi kadar toluena (ppm) dan RQ pada pekerja. Jumlah populasi sebanyak 37 pekerja, sampel penelitian diambil dengan metode accidental sampling dengan jumlah sampel 30 responden. Rumus untuk menentukan konsentrasi asupan non karsinogen toluen adalah (CxRxtExfExDt): (Wbx30x365). Hasil: Nilai konsentrasi paparan toluen lebih besar dari standar yang ditetapkan oleh peraturan ketenagakerjaan No. 5 tahun 2018 tentang K3 Lingkungan Kerja sebesar 0,2 ppm. Sebanyak 10\% pekerja berada di bawah kategori normal, 73\% di atas kategori normal dan 27\% di bawah kategori normal. Simpulan: Pada penelitian ini ditemukan temuan baru yaitu konsentrasi paparan toluena di percetakan Surabaya berada di atas normal dengan konsentrasi 0,2 ppm dan hal ini tergolong tidak normal.

Kata kunci: konsentrasi yang aman, percetakan surabaya, toluene, toluena non karsinogenik

Corresponding Author:

Ahmad Rido'i Yuda Prayogi

Email: Ahmad.ridoi.yuda-2017@fkm.unair.ac.id

Telephone: +6282234354571

(C2020 IJOSH All right reserved. Open access under CC BY NC-SA license doi: 10.20473/ijosh.v9i3.2020.360-368 Received August 15, 2020, received in revised form September 21, 2020, Accepted October 31, 2020, Published: November 2020 


\section{INTRODUCTION}

Indonesia is a country with many small, medium and large industries. The rapid development of the industry can increase employment. However, this can also increase health risks. Occupational health risks can be caused by work accidents, exposure to hazardous chemicals, risky behavior for workers, or working environment conditions that are not in accordance with the requirements. One of the industries with the risk of hazardous chemicals exposure- especially benzene- is the printing industry (Irmasari, 2018).

There is no data regarding the use of toluene in industry in Indonesia. Toluene is a solvent that is most often used in the industrial sector, including solvents for paints, glues, pharmaceutical products, thinners, inks, additives for cosmetic products, plastics industry, and synthetic fibers. Meanwhile, for the domestic use, it is found in disinfectants and adhesives (Wispriyono and Handoyo, 2016). The printing and tanning process often uses toluene (Parekh et al., 2011).

BTX is a Volatile Organic Compound (VOC), a compound containing carbon which evaporates at a certain pressure and temperature or has high vapor pressure at room temperature. The most commonly known VOC is the solvents group. Other types of VOCs such as monomers and deodorizers are widely used (Tunsaringkarn et al., 2012; Joshi and Adhikari, 2019). Toluene is a volatile organic compound (VOC) which is highly volatile at room temperature and is the most used solvent. Data from the National Institute of Occupational Safety and Health reported that there were 4.8 million workers exposed to Toluene (Phanprasit et al., 2019). BTX is a toxic chemical, both carcinogenic or triggering cancer (Gammon and Santella, 2008; Reid et al., 2012; White et al., 2014), increases oxidative stress (Bae et al., 2010) and non-carcinogenic such as affecting the hematopoietic system, central nervous system and reproductive system (Smith, 2010; Sulistyanto et al., 2020; Tualeka et al., 2020).

Volatile Organic Compound (VOC) emissions can cause the spread of pollutants or dangerous pollution because it has been linked to several health impacts and environmental development conditions (Singh A.K., Tomer Neetu, 2012; Tualeka, Tri and Jalaluddin, 2019). Several studies have shown that VOCs, even at low concentrations, can produce adverse health effects including nausea, eye and throat irritation, induction of asthma attacks, dizziness, fatigue, and mental health problems (Tunsaringkarn et al., 2012). VOCs have many types, but emphasis is placed on mono-aromatic volatile organic compounds, namely benzene, toluene, ethylbenzene, and xylene (BTEX). This type of VOC is often considered a carcinogenic compound (Heibati et al., 2018; Masekameni et al., 2018). Benzene and ethyl benzene exposure is usually associated with an increased incidence of hematopoietic cancer and a risk of leukemia (Khalade et al., 2010). Whereas toluene and xylene are not carcinogenic, but can cause adverse effects on reproductive organs. It usually occurs when the exposure is chronic at low to high concentrations (Wispriyono and Handoyo, 2016; Tualeka, Rahmawati, et al., 2019).

Benzene, Toluene and xylene (BTX) are several types of air pollutants which are Polycyclic Aromatic Hydrocarbons (PAH). PAH is formed due to incomplete combustion of organic matter, spreads in the environment and is mixed. The main sources of PAH exposure to humans are working environment, passive and active smoking (White et al., 2014) as well as food, water and air pollution (Bae et al., 2010; Almadiana and Tualeka, 2020; Oktavia et al., 2020; Sulistyanto et al., 2020).

Toxic properties of BTX in high levels of exposure cause neurotoxic symptoms. Continuous exposure to high levels of BTX can cause damage to the human bone marrow, damage to DNA in mammalian cells and damage to the immune system. Light concentrations exposure causes irregular heartbeat, dizziness, headache, nausea and even fainting. If exposure is prolonged, the initial manifestations of toxicity are anemia, leukocytopenia and thrombocytopenia (Singh A.K., Tomer Neetu, 2012; Singh et al., 2016).

Benzene and toluene exposure can also reduce levels of Leukocyte Telomere Length (LTL) (Haen and Oginawati, 2009; Sakizadeh, 2019). The main effect that can arise from xylen vapor exposure is depression in the central nervous system with symptoms such as headaches, dizziness, nausea and vomiting. All of these symptoms can occur at $100 \mathrm{ppm}$ exposure (U.S Environmental Protection Agency, 2005).

The money and time needed to reduce BTX emissions from outside sources is higher than required for the reduction of active and passive smoking. However, reducing BTX emissions from external sources is certainly more beneficial to the public and more effective in terms of reducing 
atmospheric pollution globally (Wispriyono and Handoyo, 2016). The improvement of air quality to minimize health effects in the workplace include increasing the ambient and local ventilation, replacing the solvent-based products with waterbased products, and establishing routines to maintain container closure after use (Cruz, Rivera-García and Woodward, 2014; Thetkathuek et al., 2015).

Safe concentrations of non-carcinogenic toluene can cause adverse effects on health. Based on the results of a research project, toxic effects on toluene exposure can cause cancerous (leuikimia) and noncancerous (aplastic anemia) forms (Al-Ghamdi et al. 2003; Fahrudhi 2017). The research explained that all shoe factory workers have non-carcinogenic and carcinogenic health risks. Toluene that enters through respiratory tract enters through the blood into the lungs, then it will quickly affect the workers' health in long term (Lee et al. 2005; Williams et al. 2015). The exposure of toluene that enters the nerve can cause nerve disorders. The nerve disorders are divided into two types those are neurotoxic and neuropathy (Fadhila, Soebijanto and Dr. dr. Ismail Setyopranoto, 2015).

Based on the research conducted by Irmasari, (2018) a study in Surabaya Rungkut printing industry found that high concentrations of toluene in the air could cause an increase in workers' urine hippuric acid levels (Irmasari, 2018). Gammon and Satella in their study mentioned that increased hippuric acid can have adverse effects on health, one of which is acute health ailments, eye irritation, and skin cancer (Gammon et al. 2008). Based on the research in toluene toxicology book, exposure to toluene causes nasal mucus flow or lung function at $100 \mathrm{ppm}$, but not at 10 or $40 \mathrm{ppm}$, causing eye and nose irritation, headaches, dizziness and drunk. In this study, a test of visual perception, psychomotor function, alertness and cortical function decreased due to high toluene exposure (U.S.Environmental Protection Agency 2005; Parekh et al. 2011).

Toluene is a non-carcinogenic toxin so the risk characteristics are expressed as a Risk Quotient (RQ) which can be calculated by dividing the intake value by reference (RfC). RQ is used as a benchmark for safe exposure that can be accepted by the human body. If the exposure received by workers exceeds the TLV for a long time, it can cause a disease (Zuhro, Tualeka and Harsetianingrum, 2018).

Based on research carried out by Wispriyono and Handoyo, it was found that toluene level is always below normal with $\mathrm{tE}<=8$ hours/day, $\mathrm{R}$ of $0.56 \mathrm{~m} 3 /$ hour and 18 years (Wispriyono and Handoyo 2016). Based on research performed by Fahrudi, it showed that the value of toluene exposure by RQ $>1$, tE of 10.55 hours/day and $R$ of $0.635 \mathrm{~m} 3 /$ hour, 34 years, above normal (Fahrudhi 2017). Febriantika (2017) in his research in printing industry in Semarang City found that exposure to toluene was RQ $>1$, tE 8 hours/day and R of 1.4810 $\mathrm{m} 3 /$ hour which means above normal or above the threshold. The results of research conducted by Zuhro, Tualeka and Harsetianingrum, (2018) showed that the value of toluene exposure was always above normal with RQ $>1$, tE 10 hours/day and $\mathrm{R}$ of 1.267 $\mathrm{m} 3$ /hour.

Based on various research results above, there has been no research report on the determination of safe concentration of non-carcinogenic toluene in Surabaya printing. Therefore, a research on the value of non-carcinogenic toluene concentration in Surabaya printing exposed to toluene needs to be carried out. The research objective is to determine the safe concentration of non-carcinogenic toluene in Surabaya printing. In the present research, the value of safe concentration of non-carcinogenic toluene in Surabaya printing was determined. The results of this study can provide input to the industry so that workers can avoid various diseases due to high toluene exposure.

\section{METHODS}

This is an observational analytic, crosssectional research design with a quantitative approach to calculate and describe the data collected. Calculations in this study were carried out using a number of processing application (Microsoft Excel 2010). The study was carried out in printing press exposed to toluena in Surabaya due to the use of toluene as a solvent in its production process. This research was conducted from April 5 to November 31,2019 . The population in this study were 37 workers exposed to toluene. The research sample was taken using the accidental sampling method with a sample of 30 respondents.

The variables in this study included effective doses of intake needed by each individual by calculating body weight, length of work (years), average working period in every day (hours), and working time in a week (days), Risk Quotient (RQ) and measurement of toluene concentration. Weight measurement was carried out by using a manual weighing method with a body scale. Measurements 
of working period, average daily work, and weekly working time were obtained through in-depth interviews with the respondents. The measurement of benzene in the work environment used an air sampling pump.

The inclusion criteria in this study were all workers exposed to toluene, aged $\geq 16$ years, willing to participate (signing informed consent) and able to communicate. Workers with acute physical or mental illness, those taking medication for medical conditions, and those with infections and/or acute illnesses that might suppress their immune systems as well as pregnant women were excluded from the study. The research sample was taken using accidental sampling method which resulted in 81 respondents who met the inclusion and exclusion criteria.

Questionnaires were distributed and direct interviews were conducted to obtain information on general characteristics of the subjects including age, gender, body weight, job characteristics including daily working hours, duration of work, and years of working.

The air was taken from near the breathing zone during working hours. Sampling was taken using an absorber tube (charcoal tube), a low flow pump (0.05-0.1 liter/minute), and a personal sampling pump. The absorber tube was placed between the chest and nose (breathing zone) of the worker. After sampling, the contents of the tube were removed and dissolved in a solution of carbon disulfide (CS2) and analyzed through Gas Chromatography, Flame Ionized Detector (GC/FID) based on the NIOSH method number 1501 .

The formula for calculating toluene intake in workers is:

$$
\text { Intake }-\mathrm{nc}=\frac{\mathrm{C} \times \mathrm{R} \times \mathrm{tE} \times \mathrm{fE} \times \mathrm{Dt}}{\mathrm{Wb} \times 30 \times 365}
$$

Where:

Intake-nc : Intake of non-carcinogen

$\mathrm{C}: \quad$ Agent Concentration $(\mathrm{mg} / \mathrm{m} 3)$

$\mathrm{R}$ : $\quad$ Toluene reaction rate ( $\mathrm{m} 3 /$ hour)

tE : $\quad$ Working time / day (hours)

fE : $\quad$ Working time / week (days)

Dt : $\quad$ Working time (years)

Wb: Worker's Weight $(\mathrm{kg})$

30: Non-carcinogenic Toxins

3655 :The number of days in a year
Risk quotient (RQ) was calculated using the following formula:

$$
R Q=\frac{I}{R f C}
$$

Where:

$\mathrm{I}=$ Non-carcinogenic Intake from the calculation of exposure $(\mathrm{mg} / \mathrm{kg} /$ day $)$

$\mathrm{RfC}=$ Reference Concentration (mg/kg/day)

After RQ value was calculated, effective dose per day for workers was calculated using an RQ value $>1$ using the formula below:

$$
\begin{aligned}
& \text { Effective dose of food intake }= \\
& \left\{\left(\text { Intake } n c \times \frac{M r \text { Enzyme }}{M r \text { Toxin }}\right)-(\text { C enzyme } \times 70)\right\} \times \frac{100}{A}
\end{aligned}
$$

(Tualeka et al. 2019).

Data processing was carried out after data collection and interviews with respondents were conducted. The next process included editing, coding, data entry and tabulation. Univariate analysis yielded frequency and percentage distribution.

\section{RESULTS}

This research was conducted with a sample of 30 workers with the largest body weight characteristics was 87 and the smallest was 45 . This study did not specifically explain the gender of the worker. Work is carried out on an average of 8 hours per day and 4-7 days a week. The longest period of worker worked is 24 years.

The RQ calculation results in table 1 show that if $R Q$ value $>1$, agent concentration is at risk of causing adverse health effects. If RQ $<1$ then agent concentration is not at risk of causing adverse health effects, yet can cause adverse health effects. The highest exposure to toluene levels was $2.15 \mathrm{ppm}$ and $8.09 \mathrm{mg} / \mathrm{m} 3$.

The RFC used in this study was 0.05 according to the calculation of RQ formula. The highest intake value for non-carcinogenic toluene was 0.45 , while the lowest was 0 . Based on the calculations in table 2 , from 30 respondents whose RQ values were calculated, there were 11 respondents with RQ value greater than $1(\mathrm{RQ}>1)$.

The calculation of detox to toluene-exposed workers was carried out on these 30 respondents. A total of $36 \%$ of workers had a high risk of being affected on their health. Around $64 \%$ of workers 
Table 1. The Characterization of Non-Carcinogen Risks in Surabaya Printing Workers 2019

\begin{tabular}{|c|c|c|c|c|c|c|c|c|c|}
\hline $\begin{array}{l}\text { Tolu e n e } \\
\quad \text { (ppm) }\end{array}$ & $\begin{array}{l}\text { Tolu en e } \\
(\mathbf{m g} / \mathrm{m} 3)\end{array}$ & $\begin{array}{l}\text { W e i g h t } \\
\quad(\mathrm{kg})\end{array}$ & $\begin{array}{l}\text { Average } \\
\text { working } \\
\text { t i m e } \\
\text { per day } \\
\text { (hours) }\end{array}$ & $\begin{array}{l}\text { Working } \\
\text { time per } \\
\text { week (days) }\end{array}$ & $\begin{array}{c}\text { D u r a tion } \\
\text { of working } \\
\text { (years) }\end{array}$ & $\begin{array}{l}\text { Breathing } \\
\text { rate }(\mathrm{m} 3 / \\
\text { hour })\end{array}$ & Intake & RfC & RQ \\
\hline 1 & 3.8 & 76 & 8 & 7 & 15 & 0.67 & 0.09 & 0.05 & 1.81 \\
\hline 0.04 & 0.16 & 60 & 8 & 4 & 20 & 0.62 & 0.01 & 0.05 & 0.12 \\
\hline 1 & 3.8 & 55 & 8 & 6 & 10 & 0.6 & 0.08 & 0.05 & 1.49 \\
\hline 0 & 0.01 & 53 & 8 & 7 & 15 & 0.59 & 0 & 0.05 & 0.01 \\
\hline 0.04 & 0.16 & 60 & 8 & 6 & 12 & 0.62 & 0 & 0.05 & 0.07 \\
\hline 1 & 3.8 & 68 & 8 & 6 & 5 & 0.64 & 0.03 & 0.05 & 0.65 \\
\hline 0.04 & 0.16 & 68 & 8 & 6 & 4 & 0.64 & 0 & 0.05 & 0.02 \\
\hline 0 & 0.1 & 67 & 8 & 6 & 9 & 0.64 & 0 & 0.05 & 0 \\
\hline 0 & 0.1 & 50 & 8 & 7 & 6 & 0.58 & 0 & 0.05 & 0 \\
\hline 0.04 & 0.16 & 66 & 9 & 7 & 2 & 5.59 & 0.01 & 0.05 & 0.11 \\
\hline 0.04 & 0.16 & 83 & 8 & 7 & 13 & 0.62 & 0 & 0.05 & 0.06 \\
\hline 2.15 & 8.01 & 87 & 8 & 7 & 7 & 0.7 & 0.1 & 0.05 & 2.02 \\
\hline 0.43 & 1.6 & 50 & 8 & 7 & 10 & 0.58 & 0.04 & 0.05 & 0.82 \\
\hline 2.15 & 8.09 & 60 & 8 & 6 & 24 & 0.62 & 0.45 & 0.05 & 8.87 \\
\hline 2.15 & 8.09 & 52 & 8 & 7 & 6 & 0.59 & 0.12 & 0.05 & 2.43 \\
\hline 0.43 & 1.6 & 49 & 8 & 7 & 9 & 0.57 & 0.04 & 0.05 & 0.75 \\
\hline 2.15 & 8.09 & 65 & 8 & 6 & 8 & 0.63 & 0.14 & 0.05 & 2.81 \\
\hline 0.31 & 1.15 & 65 & 8 & 6 & 1 & 0.63 & 0 & 0.05 & 0.05 \\
\hline 0.31 & 1.15 & 60 & 8 & 7 & 15 & 0.62 & 0.04 & 0.05 & 0.79 \\
\hline 2.15 & 8.09 & 55 & 8 & 6 & 14 & 0.6 & 0.28 & 0.05 & 5.47 \\
\hline 2.15 & 8.09 & 55 & 8 & 5 & 20 & 0.6 & 0.4 & 0.05 & 7.81 \\
\hline 0.43 & 1.6 & 51 & 8 & 7 & 6 & 0.58 & 0.03 & 0.05 & 0.49 \\
\hline 0.43 & 1.6 & 50 & 8 & 7 & 10 & 0.58 & 0.04 & 0.05 & 0.82 \\
\hline 2.15 & 8.09 & 60 & 8 & 7 & 13 & 0.62 & 0.25 & 0.05 & 4.8 \\
\hline 2.15 & 8.09 & 70 & 8 & 7 & 15 & 0.65 & 0.26 & 0.05 & 5.01 \\
\hline 0.43 & 1.6 & 62 & 8 & 7 & 2 & 0.62 & 0.01 & 0.05 & 0.14 \\
\hline 0.43 & 1.6 & 60 & 8 & 7 & 5 & 0.62 & 0.02 & 0.05 & 0.37 \\
\hline 0.43 & 1.6 & 45 & 8 & 6 & 10 & 0.55 & 0.05 & 0.05 & 0.88 \\
\hline 0.43 & 1.6 & 60 & 8 & 5 & 4 & 0.62 & 0.02 & 0.05 & 0.29 \\
\hline 2.15 & 8.09 & 65 & 8 & 7 & 4 & 0.63 & 0.07 & 0.05 & 1.4 \\
\hline
\end{tabular}

fell under normal RQ $<1$, which means that the agent was not at risk, yet their health is at risk if the exposure increases.

In table 2, the calculation of the safe concentration of toluene shows that the average exposure to toluene was $0.887 \mathrm{ppm}$ with a maximum value of $2.15 \mathrm{ppm}$ and the lowest value of $0 \mathrm{ppm}$. The average of $\mathrm{RQ}>1$ with a result of $1.67>1$, the highest or maximum exposure value of 8.87 with $\mathrm{RQ}>1$. The lowest value is high approaching 1 with a value of 0.88 toluene exposure.

The concentration value of toluene exposure was higher than the standard set by labor regulations
No. 5 of 2018 about occupational health and safety of the work environment by $0.2 \mathrm{ppm}$ (Ministry of Manpower, 2018).

\section{DISCUSSION}

Toluene levels with $\mathrm{RQ}=6.97$ in printing industry in Medan was compared to the normal limit of RQ $>1$ (Marganda et al. 2018). Inhalation and skin exposure to toluene among printing workers in plastic bag factories supports the finding. This suggests that the majority of workers of $R Q=9.72$ 
Table 2. The Calculation of Safe Toluene Concentration (ppm) Surabaya Printing 2019

\begin{tabular}{|c|c|c|}
\hline No & Toluene (ppm) & RQ \\
\hline 1 & 1.00 & 1.809342 \\
\hline 2 & 0.04 & 0.121743 \\
\hline 3 & 1.00 & 1.488819 \\
\hline 4 & 0.00 & 0.008231 \\
\hline 5 & 0.04 & 0.073046 \\
\hline 6 & 1.00 & 0.649315 \\
\hline 7 & 0.04 & 0.022447 \\
\hline 8 & 0.00 & 0.00425 \\
\hline 9 & 0.00 & 0.003414 \\
\hline 10 & 0.04 & 0.112967 \\
\hline 11 & 0.04 & 0.057668 \\
\hline 12 & 2.15 & 2.020519 \\
\hline 13 & 0.43 & 0.822443 \\
\hline 14 & 2.15 & 8.865256 \\
\hline 15 & 2.15 & 2.426236 \\
\hline 16 & 0.43 & 0.749459 \\
\hline 17 & 2.15 & 2.80596 \\
\hline 18 & 0.31 & 0.04972 \\
\hline 19 & 0.31 & 0.785434 \\
\hline 20 & 2.15 & 5.46574 \\
\hline 21 & 2.15 & 7.8082 \\
\hline 22 & 0.43 & 0.487461 \\
\hline 23 & 0.43 & 0.822443 \\
\hline 24 & 2.15 & 4.802014 \\
\hline 25 & 2.15 & 5.011415 \\
\hline 26 & 0.43 & 0.143584 \\
\hline 27 & 0.43 & 0.366622 \\
\hline 28 & 0.43 & 0.876938 \\
\hline 29 & 0.43 & 0.293297 \\
\hline 30 & 2.15 & 1.40298 \\
\hline Average & 0.887 & 1.678667 \\
\hline Maximum & 2.15 & 8.87 \\
\hline Minimum & 0 & 0.88 \\
\hline Above TLV & $74 \%$ & $36 \%$ \\
\hline Below TLV & $26 \%$ & $64 \%$ \\
\hline TLV & $0.2 \mathrm{ppm}$ & \\
\hline
\end{tabular}

above the threshold limit can cause respiratory problems and skin cancer (Valcke et al. 2012; Phanprasit et al. 2019).

Another research found that around $86.2 \%$ of workers experience acute respiratory problems due to exposure to toluene at work (Nakhooda et al. 2019). The research showed that the average exposure to non-carcinogenic toluene was 1.67 , which is above the threshold. If this happens continuously, it can cause a risk of disruption to the workers' health. In conclusion, printing workers with exposure to toluene are always on the edge of more dominant boundaries.

However, in contrast to the results of research conducted by (Haen and Oginawati, 2009), the results of his research indicated that not all exposure to toluene was above the threshold. In his research, it was stated that the average toluene level was $3.9399 \mathrm{ppm}$ or it could be interpreted that it was below the threshold. This research was supported by Wispriyono and Handoyo, (2016) on toll workers who stated that the toluene exposure with RQ values was below the threshold. Based on research conducted by Masekameni et al., (2018), it was stated that toluene levels have the lowest exposure among benzene, xylene, ethylbenzene, $p$-xylene and o-xylene. Based on these results, it shows that the RQ value is not always above the threshold value.

Toluene is a non-carcinogenic toxin so the risk characteristics are expressed as a Risk Quotient (RQ) which can be calculated by dividing the intake value by reference (RfC) (Rahmadani and Tualeka, 2016). The value of toluene exposure by $R Q>1, t E$ for 10.55 hours/day and R of $0.635 \mathrm{~m} 3$ /hour, and 34 years which is above normal (Fahrudhi 2017). Febriantika examined printing industry in Semarang City with toluene exposure of RQ value $>1$, tE 8 hours/day and $\mathrm{R}$ of $1,0.4810 \mathrm{~m} 3 /$ hour, meaning that the toluene exposure was above normal or above the threshold (Febriantika 2017).

A research project from Zuhro et al. (2018) showed that the value of toluene exposure was always above normal with RQ $>1$, tE 10 hours/ day and $\mathrm{R}$ of $1.267 \mathrm{~m} 3 /$ hour. According to research conducted by Tunsaringkarn et. al on gas station workers in Thailand, workers with a risk of exposure to toluene RQ $>1$ at work experienced headaches $(61 \%)$, fatigue $(29 \%)$ and throat irritation $(11 \%)$ (Tunsaringkarn et al. 2012). Other studies showed similar results that workers with $\mathrm{RQ}>1$ experienced severe headache, fatigue and cough disorders (Maryiantari et al. 2016).

In this study, about $64 \%$ of workers experienced exposure to non-carcinogenic toluene below the threshold value. However, although toluene was below normal limits, it has a high risk of health problems if inhaled continuously (Prihartini 2010).

Indrawan conducted research on workers at PT. Pertamina RU IV Cilacap. The result obtained that the most contained compound is toluene and 
caused many respondents to have health complaints that are identical to the symptoms of toluene exposure, including dizziness, nausea, weakness and short of breath. The value of toluene in the respondent's blood was at the average of $0.110 \mathrm{ppm}$, which means that it was above the threshold of 0.08 ppm (Indrawan 2014). In this study, table 2 shows that tuluene exposure was at the average of 0.887 ppm with a maximum value of $2.15 \mathrm{ppm}$ workers. These results indicate that the exposure of toluene in Surabaya printing was above the threshold.

The health effect of toluene exposure is very dangerous, in short term it can cause dermatitis (red, itchy, and dry skin), while in long-term, it can affect the nervous system, in which a number of studies on paint workers and workers in the rubberized-matting industry had long-term exposure to the potential for central nervous system damage (Heibati et al., 2018; Bioindustries, 2020). Based on the results of research conducted by Kuranchie, Angnunavuri and Attiogbe, (2019) high BTX exposure conditions can reduce or eliminate a person's level of consciousness.

The use of toluene as a solvent causes health problems in workers such as dizziness, vertigo, eye irritation, skin irritation, respiratory problems, liver, kidney, and central nervous system disorders. Toluene enters the body through 3 channels, in addition to the main route of inhalation, toluene can enter the ingestion system and skin contact. Low toluene exposure dose to the nerve can cause nerve disorders. Nerve disorders due to toluene exposure consist of two types, namely neurotoxic and neuropathy (Kanwal et al., 2011; Tualeka, Wibrata, et al., 2019).

Neurotoxic is defined as adverse changes or functional disorders of the nerves, both the central nervous system and peripheral nervous system caused by exposure to chemicals, physical and biological agents better known as neurotoxic or neurotoxic substances. This disorder results in changes in memory, attention, mood, disorientation, deviations of thought, sensory, as well as somatic, and cognitive functions as neurotoxic effects due to the use of neurotoxics (Kanwal et al., 2011; Fadhila, Soebijanto and Dr. dr. Ismail Setyopranoto, 2015).

Exposure to high levels of toluene if received by workers for a long period of time can cause chronic disease. This can affect the life expectancy of a person to be lower. Thus, companies are required to carry out periodic checks so that dangerous diseases can be prevented as early as possible (Reid et al., 2012; Jonathan Posner, James A. Russell, 2014; Demir et al., 2017).

\section{CONCLUSION}

The results found that the non-carcinogenic toluene concentration was higher than the normal limit. The RQ value of workers exposed to toluene is $\mathrm{RQ}>1$ exceeding the threshold value. Workers who are exposed continuously to toluene concentrations can have a risk of harm to their health. The majority of workers show a neurotoxic risk due to exposure to toluene in the workplace.

\section{ACKNOWLEDGEMENT}

Our thanks go to the researchers and all parties involved, as well as Universitas Airlangga for providing grant assistance.

\section{REFERENCES}

Al-Ghamdi, S. S., Raftery, M. J. and Yaqoob, M. M. (2003) 'Organic Solvent-Induced Proximal Tubular Cell Toxicity via Caspase-3 Activation', Journal of Toxicology - Clinical Toxicology, 41(7), pp. 941-945.

Almadiana, C. S. and Tualeka, A. R. (2020) 'Determination of Safe Benzene Concentration at Ciputat Gas Station', Indian Journal of Forensic Medicine and Toxicology, 14(1), pp. 183-188.

Bae, S. et al. (2010) 'Exposures to particulate matter and polycyclic aromatic hydrocarbons and oxidative stress in schoolchildren', Environmental Health Perspectives, 118(4), pp. 579-583.

Bioindustries (2020) 'Efek Kesehatan Jangka Panjang dari Paparan Toluena dalam Thinner'. Yogyakarta: Bioindustries.

Cruz, S. L., Rivera-García, M. T. and Woodward, J. J. (2014) 'Review of Toluene Actions: Clinical Evidence, Animal Studies, and Molecular Targets', Journal of Drug and Alcohol Research, 3(October), pp. 1-8.

Demir, M. et al. (2017) 'Effects of Acute Toluene Toxicity on Different Regions of Rabbit Brain', Analytical Cellular Pathology, 2017, pp. 1-6.

Pratamasari, F., Soebijanto, and Setyopranoto, I. (2015) Kejadian Neuropati Saraf Tepi Pada Pekerja Percetakan Ofset Yang Terpajan Toluen Inhalasi. Thesis. Yogyakarta: Faculty of Medicine Universitas Gajah Mada.

Fahrudhi, H. (2017) 'Risiko Menderita Kanker Dan Non Kanker Pada Pekerja Terpapar Benzena Di Home Industrysepatu Kelurahan Tambak Oso Wilangun Surabaya', The Indonesian Journal of Occupational Safety and Health, 6(1), pp. 68-77. 
Febriantika, D. ; S. B. (2017) 'Analisis Risisko Kesehatan Pajanan Benzena Di Industri Percetakan X Kota Semarang', Jurnal Kesehatan Masyarakat, 5(1), pp. 430-437.

Gammon, M. D. and Santella, R. M. (2008) 'PAH, genetic susceptibility and breast cancer risk: An update from the Long Island Breast Cancer Study Project', European Journal of Cancer, 44(5), pp. 636-640.

Haen, M. T. and Oginawati, K. (2009) 'Hubungan Pajanan Senyawa Benzena, Toluena dan Xylen dengan Sistem Hematologi Pekerja di Kawasan Industri Sepatu', Farmasi ITB, pp. 1-4.

Heibati, B. et al. (2018) 'Biomonitoring-based exposure assessment of benzene, toluene, ethylbenzene and xylene among workers at petroleum distribution facilities', Ecotoxicology and Environmental Safety. Elsevier Inc., 149(July 2017), pp. 19-25.

Indrawan, D., Oginawati, K. (2014) 'Analisis Paparan BTX terhadap Pekerja di PT. Pertamina RU IV Cilacap', Jurnal Teknik Lingkungan, 20(2), pp. 132-141.

Irmasari, F. (2018) 'Kadar Toluen di Udara Lingkungan Kerja Berkorelasi terhadap Kadar Asam Hipurat Urine pada Pekerja Percetakan di Rungkut Surabaya', Jurnal Kesehatan Lingkungan, 10(2018), pp. 328-335.

Jonathan Posner, James A. Russell, and B. S. P. (2014) 'Review of toluene action: clinical evidence, animal studies and molecular targets', Journal Drug Alcohol, 23(1), pp. 1-7.

Joshi, D. R. and Adhikari, N. (2019) 'An Overview on Common Organic Solvents and Their Toxicity', Journal of Pharmaceutical Research International, 28(3), pp. 1-18.

Kanwal, R. et al. (2011) 'Occupational lung disease risk and exposure to butter-flavoring chemicals after implementation of controls at a microwave popcorn plant', Public Health Reports, 126(4), pp. 480-494.

Ministry of Manpower (2018) Peraturan Pemerintah Ketenagakerjaan No. 5 Tentang K3 Lingkungan Kerja. Jakarta: Ministry of Manpower.

Khalade, A. et al. (2010) 'Exposure to benzene at work and the risk of leukemia: A systematic review and meta-analysis', Environmental Health: A Global Access Science Source, 9(1), pp. 1-8.

Kuranchie, F. A., Angnunavuri, P. N. and Attiogbe, F. (2019) 'Occupational Exposure of Benzene, Toluene, Ethylbenzene and Xylene (BTEX) to Pump Attendants in Ghana: Implications for policy guidance', Cogent Environmental Science. Cogent, 5(1), pp. 1-18.

Lee, C. R. et al. (2005) 'Neurobehavioral changes of shipyard painters exposed to mixed organic solvents', Industrial Health, 43(2), pp. 320326.

Marganda, S., Ashar, T. and Nurmaini, N. (2018) 'The Effect of Toluene Exposure on Central Nervous Disorder among Printing Workers', Indonesian Journal of Medicine, 3(3), pp. 125-133.

Maryiantari, E. S. and Murtiana, P. T. (2016) Risk Assessment Pajanan Toluena Pada Pekerja Pengrajin Sepatu Di Kelurahan Tambak Oso Wilangun Surabaya. Thesis. Surabaya: Faculty of Public Health, Universitas Airlangga.

Masekameni, M. D. et al. (2018) 'Risk Assessment of Benzene, Toluene, Ethyl Benzene, and Xylene Concentrations from the Combustion of Coal in a Controlled Laboratory Environment', International Journal of Environmental and Public Health, 16(9), pp. 1-18.

Nakhooda, F., Sartorius, B. and Govender, S. M. (2019) 'The effects of combined exposure of solvents and noise on auditory function - a systematic review and meta-analysis', South African Journal of Communication Disorders, 66(1), pp. 1-11.

Oktavia, B. et al. (2020) 'Determination of Safe Benzene Concentration in Tank Car Crew at PT Pertamina Patria Niaga', Indian Journal of Forensic Medicine and Toxicology, 14(2), pp. 218-223.

Parekh, A. K. et al. (2011) 'Managing multiple Chronic Conditions: A Strategic Framework for Improving Health Outcomes and Quality of Life', Public Health Reports, 126(4), pp. 460-471.

Phanprasit, W. et al. (2019) 'Inhalation and dermal exposure to toluene among printing workers in a plastic bag factory', Journal of Health Research, 33(1), pp. 68-79.

Prihartini, N. (2010) 'Analisis Risiko Kesehatan Pajanan Toluen Pada Pekerja Bengkel Sepatu "X" Di Kawasan Perkampungan Industri Kecil (Pik) Pulogadung Jakarta Timur Tahun 2010'.

Rahmadani, R. and Tualeka, A. R. (2016) 'Health Risk Characteristic Due to Air Pollution Exposure in Shoe Soles Workers (around Bubutan Road in Surabaya city)', Jurnal Kesehatan Lingkungan, 8(2), p. 164.

Reid, B. C. et al. (2012) 'Research opportunities for cancer associated with indoor air pollution from 
solid-fuel combustion', Environmental Health Perspectives, 120(11), pp. 1495-1498.

Sakizadeh, M. (2019) 'Spatiotemporal Variations and Characterization of the Chronic Cancer Risk Associated with Benzene Exposure', Ecotoxicology and Environmental Safety, 182(July), pp. 1-11.

Singh, A. K. et al. (2016) 'High oxidative Stress Adversely Affects NFкB Mediated Induction of Inducible Nitric Oxide Synthase in Human Neutrophils: Implications in Chronic Myeloid Leukemia', Nitric Oxide, 58(August), pp. $28-41$.

Singh A.K., Tomer Neetu, J. C. . (2012) 'Monitoring, Assessment and Status of Benzene, Toluene and Xylene Pollution in the Urban Atmosphere of Delhi, India', Research Journal of Chemical Sciences, 2(4), pp. 2231-606.

Smith, M. T. (2010) 'Advances in Understanding Benzene Health Effects and Susceptibility', Annual Review of Public Health, 31(April), pp. 133-148.

Sulistyanto, R. A. et al. (2020) 'Safe Concentration of Benzene Exposure to Worker' $\mathrm{s}$ in Gas Station at the Area of Diponegoro University, Semarang', Indian Journal of Forensic Medicine \& Toxicology, 14(2), pp. 2049-2054.

Thetkathuek, et al. (2015) 'Neuropsychological Symptoms among Workers. Exposed to Toluene and Xylene in Two Paint Manufacturing Factories in Eastern Thailand', Advances in Preventive Medicine, 2015, pp. 1-10.

Tualeka, A. R., et al. (2019) 'Association Between Toluene Inhalation Exposure and. Demography Towards Risk of Neurotoxic: A Cross-Sectional Study at Plastic Sack Industry Workers in Indonesia', Global Journal of Health Science, 11(2), pp. 20-27.

Tualeka, A. R., Rahmawati, P., et al. (2019) 'The cost prediction for chromium detox using foods. intake containing glutathione at the leather tanning industry in Magetan, Indonesia', Open Access Macedonian Journal of Medical Sciences, 7(21), pp. 3698-3703.
Tualeka, A. R. et al. (2020) 'Determination Reference of Concentration ( RfC ) Xylen Exposure Based on Xylen NOAEL in White Rats and Workers, Body Weight and Height in Surabaya Car Painting Area , Indonesia', Indian Journal of Forensic Medicine \& Toxicology, 14(3), pp. 1709-1715.

Tualeka, A. R., Tri, M. and Jalaluddin, J. (2019) 'Analisis Risiko Pajanan Benzena Risk Assessment, Risk Management, and Risk Communication'. Surabaya: Dinas Perpustakaan Dan Kearsipan Provinsi Jawa Timur, p. 114.

Tunsaringkarn et al. (2012) 'Occupational Exposure of Gasoline Station Workers to BTEX Compounds in Bangkok, Thailand.', International Journal of Occupational and Environmental Medicine, 3(3), pp. 117-126.

U.S.Environmental Protection Agency (2005) Toxicological review of Toluene. washington DC: Environmental Protection Agency.

Valcke, M., Nong, A. and Krishnan, K. (2012) 'Modeling the human kinetic adjustment factor for inhaled volatile organic chemicals: Whole population approach versus distinct subpopulation approach', Journal of Toxicology, 14(4), pp. $1-14$.

White, A. J. et al. (2014) 'Indoor air pollution exposure from use of indoor stoves and fireplaces in association with breast cancer: A case-control study.', Environmental Health, 13(108), pp.112

Williams, R. and Wilbur, S. (2015) 'ATSDR Toxicological Profile: Toluene'. United State: Department of Health and Human Services, Public Health Service.

Wispriyono, B. and Handoyo, E. (2016) 'Risiko Kesehatan Pajanan Benzena, Toluena Dan Xylena Petugas Pintu Tol', KESMAS: Jurnal Kesehatan Masyarakat, 11(2), pp. 96-102.

Zuhro, R., Tualeka, A. R. and Harsetianingrum, R. A. (2018) 'Determination of the safe duration of benzene non-carcinogenic exposure in motor workshop area', Indian Journal of Public Health Research and Development, 9(11), pp. 582-586. 